
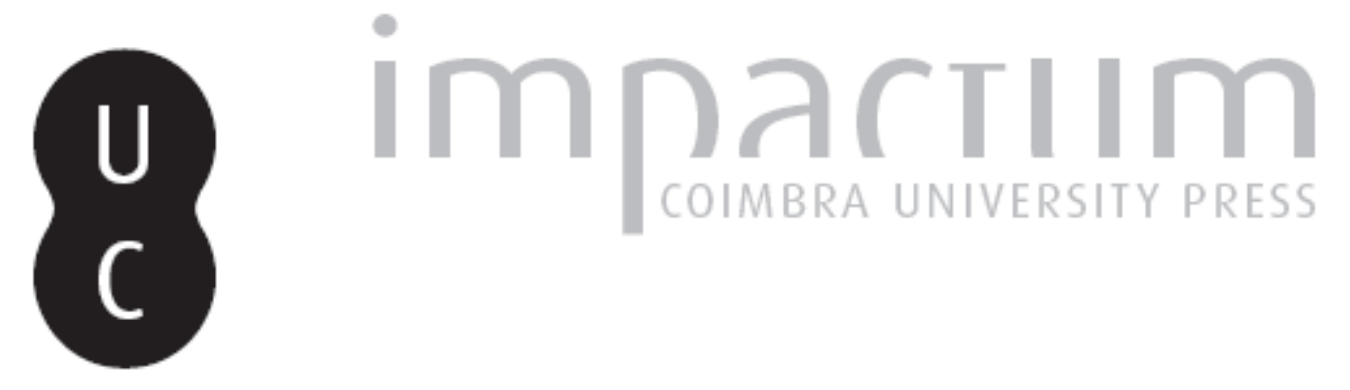

\title{
Pastorais de alguns bispos portugueses por ocasião das invasões francesas
}

Autor(es): $\quad$ Pereira, Isaías da Rosa

Publicado por: Imprensa da Universidade de Coimbra

URL persistente:

URI:http://hdl.handle.net/10316.2/43778

DOI:

DOI:https://doi.org/10.14195/2183-8925_10_19

Accessed : $\quad$ 26-Apr-2023 16:19:13

A navegação consulta e descarregamento dos títulos inseridos nas Bibliotecas Digitais UC Digitalis, UC Pombalina e UC Impactum, pressupõem a aceitação plena e sem reservas dos Termos e Condições de Uso destas Bibliotecas Digitais, disponíveis em https://digitalis.uc.pt/pt-pt/termos.

Conforme exposto nos referidos Termos e Condições de Uso, o descarregamento de títulos de acesso restrito requer uma licença válida de autorização devendo o utilizador aceder ao(s) documento(s) a partir de um endereço de IP da instituição detentora da supramencionada licença.

Ao utilizador é apenas permitido o descarregamento para uso pessoal, pelo que o emprego do(s) título(s) descarregado(s) para outro fim, designadamente comercial, carece de autorização do respetivo autor ou editor da obra.

Na medida em que todas as obras da UC Digitalis se encontram protegidas pelo Código do Direito de Autor e Direitos Conexos e demais legislação aplicável, toda a cópia, parcial ou total, deste documento, nos casos em que é legalmente admitida, deverá conter ou fazer-se acompanhar por este aviso.

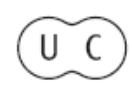


REVISTA DE HISTORIA DAS IDEIAS IO
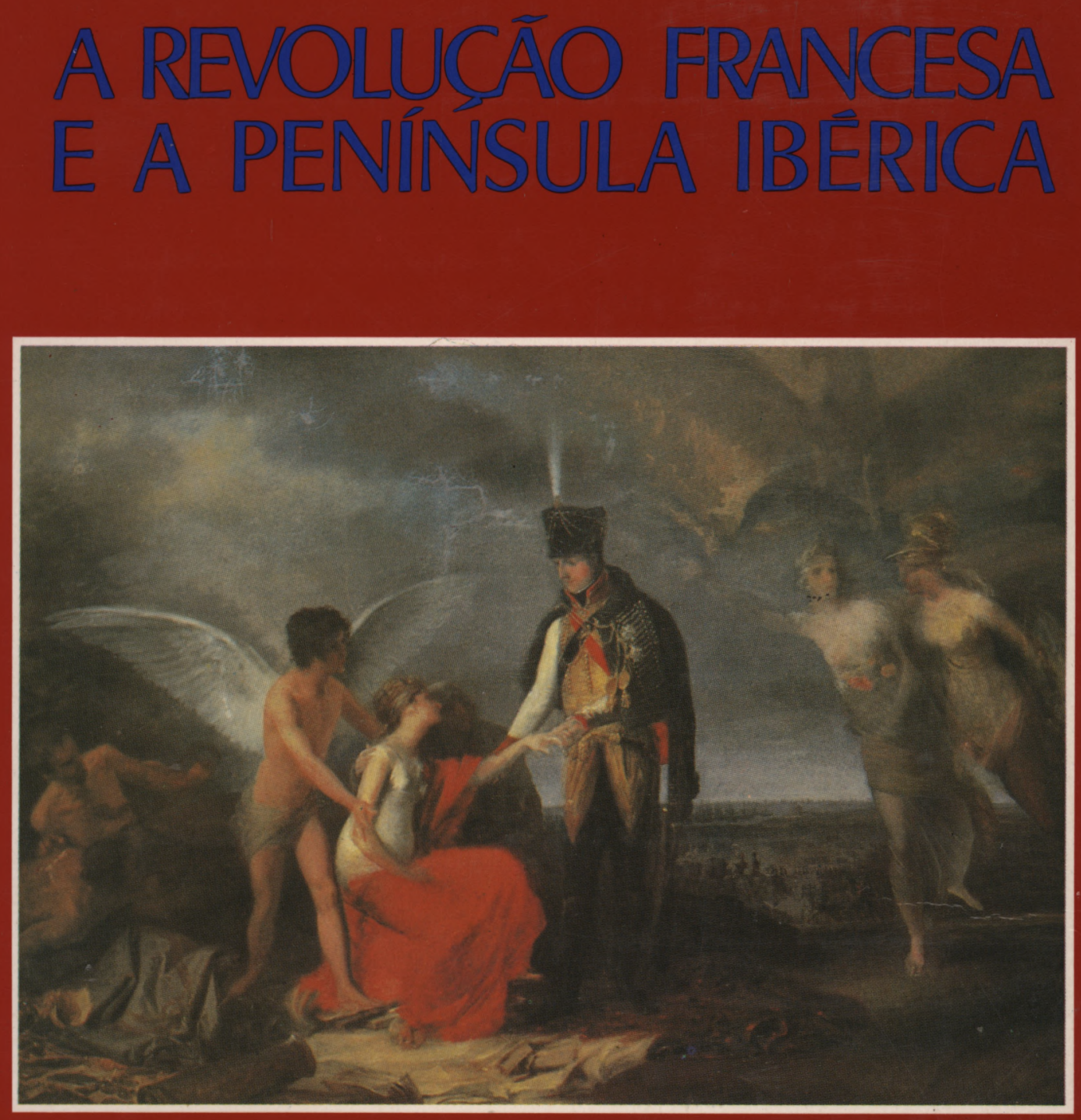

INSTITUTO DE HISTÖRIA E TEORIA DAS IDEIAS FACULDADE DE LETRAS 
ISAIAS DA ROSA PEREIRA *

\section{PASTORAIS DE ALGUNS BISPOS PORTUGUESES POR OCASIÃO DAS INVASÕES FRANCESAS}

A ocupação de um país por exércitos estrangeiros causa necessariamente graves problemas aos membros da hierarquia católica.

Alguns prestarão apoio ao ocupante, mas esse caso não é corrente, pois o espírito patriótico não se apaga, antes pelo contrário se reforça.

Não pode, porém, o Bispo deixar de velar pelo bem comum dos cristãos e até dos não cristãos; deve ser mediador para a paz (não o único, necessariamente); tem de procurar que a opressão e a morte não invadam o País.

A situação do Bispo é, assim, das mais delicadas e complexas. Por experiência aprendida em países ocupados duas vezes neste século - Bélgica e França -, sabemos o que isto custou a muitos bispos, sacerdotes e leigos.

$\mathrm{Na}$ altura das invasões francesas e já antes, quando da declaração de guerra da Espanha em 1801, alguns bispos portugueses publicaram documentos, quase todos conhecidos, mas nem sempre bem interpretados no seu contexto temporal e humano.

Os documentos de que vamos ocupar-nos são os seguintes:

1. Pastoral do Patriarca D. José II (Cardeal Mendonça), de 14 de Março de 1801.

2. Pastoral do mesmo, de 30 de Maio de 1801.

3. Pastoral do mesmo, de 8 de Dezembro de 1807.

4. Pastoral do Inquisidor-Geral D. José Maria de Melo, Bispo do Algarve, de 22 de Dezembro de 1807, dirigida «a todos os fiéis da Santa Igreja Lusitana».

* Faculdade de Letras da Universidade de Lisboa. 
5. Três pastorais do Arcebispo de Évora D. Fr. Manuel do Cenáculo Vilas Boas, de 30 de Julho de 1808, de 6 de Agosto de 1808, de 8 de Setembro de 1808, e ainda um quarto documento que é uma exortação datada de 2 de Fevereiro de 1809.

6. Carta dos Principais Silva, Castro e Decano em nome do Colégio dos Principais da Igreja Patriarcal de Lisboa, sede vacante, de 28 de Outubro de 1808.

7. Finalmente, um documento não episcopal, mas de extraordinário interesse. Trata-se de notas manuscritas encontradas num pequeno caderno do Arquivo da Cúria Patriarcal, escritas por um amanuense da Cúria, relatando alguns acontecimentos ocorridos em Lisboa nos anos de 1808 e 1809.

No dia 27 de Fevereiro de 1801, o rei de Espanha declarou guerra a Portugal, quando da recusa de fechar os portos aos navios ingleses.

O Patriarca de Lisboa D. José II publicou nessa altura duas pastorais sobre a difícil situação, em que o País se encontrava.

$\mathrm{Na}$ de 14 de Março de 1801, depois de explicar aos fiéis - problema que a Espanha e a França levantavam, exigindo - bloqueio dos nossos portos a todos os navios ingleses, invoca as sem-razões do soberano espanhol, a quem Portugal socorrera na guerra do Rossilhão com "dispêndio de sangue de seus vassalos e de avultadas somas do seu real erário», tendo além disso protegido navios espanhóis vindos da América. O Patriarca apela a todos os fiéis para que dêem testemunho de valor, zelo e fidelidade na defesa do Estado, porque a guerra era defensiva e não provocada pelo Príncipe Regente.

Considera depois que todo o bem só de Deus se deve esperar e por isso determina que nas igrejas se façam preces públicas por três dias sucessivos, com exposição do Santíssimo Sacramento, e que se reze em todas as missas a oração Pro tempore belli. Exorta, finalmente, os cristãos a fazer preces pela paz.

Tendo as tropas espanholas penetrado já no nosso território, publica nova pastoral a 30 de Maio de 1801, explicando aos fiéis que Portugal se vê constrangido a «repelir a força com a força e a resistir a uma tão injusta agressão», dado que essa guerra era «tão contrária aos vínculos do sangue e dos tratados que unem estreitamente as duas monarquias, e não menos oposta à boa fé e promessas de Sua Majestade Católica».

Nestas circunstâncias, exorta de novo os fiéis a mostrar o seu valor, zelo e fidelidade ao Príncipe, e pede se intensifiquem as orações pelas «mãos e intercessão de nossa santíssima $\mathrm{Pa}$ droeira e protectora, a Virgem Santíssima». Determina que se continue a rezar na missa a oração Pro tempore belli e que 
não «cessem de rogar a Deus com tão justo motivo, afastando-se de tudo o que possa fazer menos aceites as nossas orações».

Passados seis anos, o Patriarca vê-se confrontado com outro problema. Portugal fora ocupado por tropas francesas.

No dia 8 de Dezembro de 1807, assina uma pastoral, de que possuímos o original e que tem sido mal entendida e pior interpretada. necessário ler integralmente o texto e não simples extractos, como se tem feito. Por outro lado, é preciso conhecer a situação em que se encontrava D. José II.

O velho Patriarca, com 83 anos, estava já muito doente, vigiado pelos invasores na sua própria casa, tendo falecido a 11 de Fevereiro de 1808, dois meses depois de ser obrigado a assinar o famoso documento.

A pastoral tem sido lida apenas na parte em que o decrépito Patriarca louva Napoleão e o seu exército. As considerações anteriores e posteriores não têm sido ponderadas.

Primeiramene, o Patriarca fala na qualidade de Pastor de uma diocese ocupada por exércitos estrangeiros deste modo:

- o seu ministério de bispo «dirige-se» a unir os fiéis em caridade cristã, para se conseguir o sossego e a paz, «de que todos necessitamos nas presentes circunstâncias»;

- pois todos sabem «pela própria experiência a situação em que nos achamos»;

- apesar disso "a Divina Clemência, no meio de tantas tribulações nos favorece», certamente por não ter havido ainda derramamento de sangue e os horrores da morte que uma ocupação costuma trazer;

- sendo assim, é necessário ser fiel «aos imutáveis Decretos da Sua Divina Providência», para o que se requer viver com coração contrito e humilhado, agradecer-lhe «tantos e tão contínuos benefícios, que de Sua liberal mão temos recebido»;

- e um desses benefícios é «a boa ordem e quietação com que neste Reino tem sido recebido um grande Exército, o qual, vindo em nosso socorro, nos dá bem fundadas esperanças de felicidade, benefício que igualmente devemos à actividade e boa direcção do General em chefe, que o comanda, cujas virtudes são por nós há muito conhecidas».

Estas últimas frases são certamente ditadas ao Prelado, mas o restante é digno de um Bispo, a quem só interessa o bem-estar e o sossego públicos, a união dos cristãos em caridade e o grande empenho em que se não derrame sangue.

No seguimento destas considerações, vem um longo parágrafo, muitas vezes citado com intenção de acusar o Patriarca de «colaboracionista». O texto integral é o seguinte: 


\section{Revista de História das Ideias}

«Não temais, amados filhos, vivei seguros em vossas casas e fora delas; lembrai-vos que este Exército é de Sua Majestade o Imperador dos Franceses e Rei de Itália, NAPOLEÃO o Grande, que Deus tem destinado para amparar e proteger a Religião e fazer a felicidade dos povos;

Vós o sabeis, o Mundo todo o sabe.

Confiai com segurança inalterável neste Homem prodigioso, desconhecido de todos os séculos, Ele derramará sobre nós as felicidades da Paz, se Vós respeitáreis as suas determinações; se vos amáreis todos mutuamente, nacionais e estrangeiros com fraternidade.

Deste modo a Religião e os seus ministros serão sempre respeitados; não serão violadas as clausuras das Esposas do Senhor; o Povo todo será feliz, merecendo tão Alta Protecção.

Meus filhos, fazei-o assim, para cumprireis fielmente como que Nosso Salvador Jesus Cristo tanto nos recomendou:

Vivei sujeitos aos que vos governam, não só pelo respeito que se lhes deve, mas porque a própria consciência nos obrigan.

Neste parágrafo há uma clara alusão a palavras da Bíblia: «desconhecido de todos os séculos», que evidentemente se não podem aplicar a Napoleão, nem a qualquer chefe político, pois referem-se ao Messias.

"Vivei sujeitos aos que vos governam não só pelo respeito que se lhes deve....», são alusões não a palavras de Cristo, mas a uma frase de S. Paulo na Primeira Carta a Timóteo (2/1-2):

"Obsecro igitur primum omnium fieri obsecrationes, orationes, postulationes, gratiarum actiones, pro omnibus hominibus,

pro regibus et omnibus qui in sublimitate sunt, ut quietam et tranquilam vitam agamus in omni pietate et castitate».

Refere-se igualmente à advertência que se encontra na Primeira Carta de S. Pedro (2/13-15):

"Subiecti igitur estote omni humanae creature propter Deum: sive regi quasi praecellenti, sive ducibus tanquam $a b$ eo missis ad vindictam malefactorum, laudem vero bonorum, quia sic est voluntas Dei».

Antes de mais, é necessário não esquecer que o cristianismo nunca tentou modificar a ordem estabelecida nem o direito dos povos, a não ser naquilo em que se oponham frontalmente à moral e aos direitos da pessoa humana. Mesmo assim, só o fez procurando formar a consciência dos fiéis para viverem na paz e na tranquilidade, influenciando as estruturas sociais para que estas se fossem modificando a pouco e pouco. Nunca propugnou uma revolução a não ser a do Evangelho. 
E evidente que quem redigiu esta pastoral estava perfeitamente coagido e teve de inserir nela as palavras laudatórias a Napoleão, o Grande, mas enquadrou-as em textos que pretendem evitar tumultos, pacificar os ânimos, evitar derramamento de sangue e permitir a continuação da celebração dos actos do culto nas igrejas bem como evitar o assalto aos conventos.

Como se verá numa carta do Cabido de Lisboa, sede vacante, dirigida ao Príncipe Regente, após a saída de Junot, não foi somente esta pastoral que as autoridades eclesiásticas foram obrigadas a assinar. Os cónegos Principais que governavam a diocese após o falecimento, em 11 de Fevereiro de 1808, do Patriarca D. José II sentem bem a desonra dos documentos que foram obrigados a assinar. Dizem eles:

«o que nos sucedeu no desditoso tempo em que um Governo intruso nos violentava à assinatura de papéis que maculariam a nossa honra e gravariam nossa consciência se não fosse tão constante a Deus e ao Mundo a nossa lealdade, e a opressão em que nos achávamos constituídos".

Há, porém, uma pastoral que não temos visto citar e de que possuímos um exemplar. Esta suscita comentários um pouco diferentes, embora tenha sido certamente redigida sob coacção.

Nesse ano de 1807, a Inquisição era já um organismo adormecido. Os chamados processos inquisitoriais do século XIX que se conhecem (em número um pouco superior a mil) são constituídos quase só por denúncias que não tiveram seguimento.

Contudo, havia um Inquisidor-Geral, que era o Bispo do Algarve, D. José Maria de Melo (1).

Ora, este Bispo dirige uma pastoral «A todos os Fieis da Santa Igreja Lusitana», com data de 20 de Dezembro de 1807.

Comecemos por esclarecer que não existe e nunca existiu uma «Igreja Lusitana». A Igreja é Católica (isto é, universal) e não há igrejas regionais, para empregar a expressar hoje tanto em moda.

Em Portugal, como em qualquer País, existem comunidades católicas e a única expressão que se poderia usar era a de «Fiéis da Igreja Católica que vivem em Portugal».

Por outro lado, nenhum bispo tem competência para dirigir uma pastoral ou qualquer outro documento destinado a ultrapassar os limites territoriais da sua Diocese.

(1) Quem governava a diocese do Algarve era D. Francisco Gomes do Avelar, mas D. José Maria de Melo continuava a usar o título de bispo do Algarve. 
Esta pastoral de D. José de Melo constitui um abuso; mas como se vê pelo seu teor, foi igualmente imposta pelo invasor.

Compreende-se perfeitamente que o general francês e os seus conselheiros se tenha apercebido de que, apesar de tudo, ainda havia em Portugal um Inquisidor-Geral, com jurisdição em todos os casos de heresia (e não outra), e que era uma autoridade com relativo poder moral. Talvez a Inquisiçãa ainda atemorizasse algumas pessoas, sobretudo o povo simples. Entenderam, por isso, ser necessário obter dele uma declaração que abrangesse todo o território, dado que os outros Bispos não o fariam facilmente.

A pastoral comeca por recordar a do Patriarca D. José II, transcrevendo quase literalmente a primeira parte, sem qualquer novidade. Termina com a declaração de que ele, Inquisidor-Geral, pretende "concorrer, como tanto devemos, para os mesmos fins [quietação, sossego e paz], lembramos ao resto dos fiéis desta Igreja Lusitana».

Aqui igualmente $\mathrm{D}$. José Maria de Melo ultrapassa todas as medidas, visto que já nem tinha jurisdição na diocese do Algarve, e como Inquisidor-Geral só possuía faculdades para inquirir acerca de crimes de heresia.

Contudo. D. José Maria de Melo acrescenta um parágrafo dirigido a todos «os Regulares deste Reino», para que lembrem aos fiéis «o quanto lhes é necessário esse sossego, essa paz, essa união, em recomendar a qual não poderá haver nunca demasia».

Ultrapassa de novo tudo o que é razoável, pois não consta que o Inquisidor-Geral fosse superior de nenhuma Ordem Religiosa ou tivesse jurisdição sobre qualquer delas.

$\mathrm{Na}$ parte final do documento reduz-se à sua função, mandando às «Mesas das Inquisições deste Reino a façam publicar e afixar nas igrejas dos seus distritos, na forma do costume», a fim de que o documento "chegue à notícia de todos».

Apesar de se dirigir agora aos seus subordinados - os inquisidores -, continua a ultrapassar a sua competência, porquanto a Inquisição não tinha jurisdição para afixar nas igrejas um documento de tal natureza. Se algum pároco ou bispo o proibisse, estaria no seu pleno direito. Ignoramos que publicidade terá sido dada a tão insólito documento.

Seja como for, o ocupante serviu-se deste Bispo, certamente coagido, para divulgar o texto que obrigara o Patriarca a assinar. Conseguiu um estratagema para divulgar as virtudes de Napoleão, o Grande, e procurar tranquilizar o povo.

Três pastorais do Arcebispo de Évora D. Fr. Manuel do Cenáculo Vilas Boas, de que damos notícia, são documentos 
flagrantes e bem expressivos da coacção a que os Prelados estiveram sujeitos.

Não conhecemos os originais, mas existem cópias no Arquivo Distrital e Biblioteca Pública de Évora, que são certamente da época.

O copista iniciou a transcrição das duas primeiras pastorais com uma nota explicativa que é para nós do maior interesse.

\section{Pastoral de 30 de Julho de 1808}

«Pastoral que os Generais do Exército Francês, com as armas na mão, obrigaram Sua Ex. ${ }^{a}$ Revma. a escrever».

É inegável que o texto foi ditado. O Bispo não escreveria tal coisa. Aliás há frases que são semelhantes às que tinham obrigado a assinar ao Patriarca de Lisboa.

«Quis a Providência Divina que a nossa obediência e sujeição fosse dirigida e determinada pelo Governo do Invencível Napoleão. E necessário assentar em base firme para a segurança dos nossos passos. A instrução apostólica não se ocupa com questões, o que de direito se nos apresenta é o que temos nas Sagradas Escrituras: obedecer a quem nos preside. Isto assim observado vem a tranquilidade com todos os seus bens consecutivos. A este desempenho vos exorto e aconselho, certos em que esta obediência e acção cristã não há lugar de questões.... Isto assim bem entendido e tomado em justa resolução cumpramos obedecendo aos Superiores da actual situação e do Império do Invencível Imperador e Rei Napoleão, e entremos em sossego no governo das nossas vidas».

\section{Pastoral de 6 de Agosto de 1808}

«Pastoral que o Exmo. e Revmo. Senhor Arcebispo de Evora, obrigado pelos Generais do Exército Francês, escreveu à sua vista, proibindo ao clero o uso de armas».

\section{Pastoral de 2 de Fevereiro de 1809}

O Arcebispo, liberto já da coacção, publica nova pastoral, em que permite ao clero o uso de armas, em certas condições. Apela primeiramente para o espírito de vida cristã próprio do clero, mas declara que nas circunstâncias do momento seria lícito para se defender, evitar os prejuízos da Pátria, salvá-la da tirania inimiga e dos seus tristes efeitos. 
Declara expressamente que tinha sido obrigado a escrever outra coisa, proibindo o clero de usar armas:

"....de cujo Conde General e seus Ajudantes dentro dos nossos lares ouvimos o preceito de que por força de uma Proclamação proibíssemos o nosso clero o uso das armas, o qual já então seria inútil e perdido. Quando porém outros tempos pedem outros costumes, quando a Religião e a Pátria com seus interesses, afecto e comodidade perigam, quando as vidas, ainda pessoais do clero se acham ameadas de ferocíssima e incontinente invasão, para este caso é que se reservam as excepções do Direito Comum».

Estes documentos são claros. Os Prelados escreveram-nos sob ameaças. Não tinham qualquer intenção de renegar a Pátria, como escreveu o Professor Doutor Joaquim Veríssimo Serrão:

«.... alto clero assumiu a posição de cautela que as circunstâncias impunham, alertando os fiéis para quaisquer actos de desobediência à ocupação francesa e que dessem origem a efusões de sangue. $O$ chamamento aos deveres espirituais foi norma de todos os prelados. E quando alguns, por força da grave conjuntura, invocaram a obediência devida a Napoleão como protector do Reino, não o fizeram por sentimento aberto de francesia, mas apenas para fomentar sentimentos de esperança no ânimo da população» (2).

Refiro finalmente as notas que um anónimo funcionário da Cúria Patriarcal de Lisboa escreveu num minúsculo caderno que contém a lista dos desembargadores e escrivães do Tribunal Eclesiástico de Lisboa entre 1797 e 1811.

As notas são da época, isto é, escritas em 1808 e 1809, e foram-no sem intenção de fazer história. Daí o seu interesse.

Por elas se pode avaliar um pouco como o povo não esteve ao lado do exército francês.

Reproduzimo-las tal como foram escritas, actualizando a ortografia excepto na palavra JINOT.

"Aos 16 dias do mês de Agosto, em 3." feira, do ano de 1808 saíram de Lisboa o General do Exército francês em Portugal, JINOT, com todos os-oficiais majores da dita nação, levando consigo tudo o que tinham em seu poder, de dinheiro, prata e ouro em barra, toda artilheria de Lisboa com todos os apetrechos de guerra que estavam nos Arsenais Reais, gado muar, cavalos e carruagens da casa Real, ficando somente um General para governar a tropa francesa que ficou de guarnição, junto com os doentes que estavam nos hospitais».

(2) Historia de Portugal (1807-1832), Lisboa, ed. Verbo, 1984, vol. II, pp. 27-28. 
«Domingo 24 de Julho arcabusaram um homem, que tinha sido correio da fundição, por falar mal do Exército francês e trazer a divisa da tropa inimiga, no Terreiro do Paço».

«Em 7 de Fevereiro principiou a oração na missa por o Imperador. Aos 2 de Fevereiro tomou posse de Portugal o Imperador; acabou a Regência e principiou o Governador, o General Ginot».

Como se sabe, a insolência de Junot foi tal que mandou substituir na oração da missa, que então se usava, o nome do rei português pelo de Napoleão. Portugal estava conquistado para a França, deixava de ser um País livre. Como deve ter sido amarga esta ordem dada aos sacerdotes da época! Era não só uma amarga provocação mas até uma profanação. Nem Napoleão, nem Junot tinham qualquer interesse religioso; serviam-se apenas da Igreja para os seus tresloucados desejos de domínio.

A última nota tem interesse histórico porque indica a data exacta do falecimento do Cardeal Patriarca D. José II:

«5.a feira 11 de Fevereiro de 1808 morreu o Ex.mo Sr. Patriarca José 2..$^{\circ}$ por as onze horas e 45 minutos da noite. Se deu à sepultura em o dia de sábado às 9 horas da noite defronte do altar de $\mathbf{N}$. Sra. sua madrinha onde se abriu a sepultura, que custou muito a abrir por ter encontrado com uma rocha. E em 4.' feira 17 do mesmo mês se fez o funeral na Sta. Igreja Patriarcal, por mandado do Exmo. Colégio [isto é, o Colégio dos Cónegos chamados Principais], Sé vacante. Assistiu todo o corpo da Relação Patriarcal».

As notícias que aqui reunimos têm antes de tudo a finalidade de chamar a atenção para documentos menos conhecidos ou deficientemente interpretados. As notas finais são totalmente inéditas.

No nosso entender, as pastorais referidas mereciam muitos outros comentários, que a brevidade do tempo concedido não permitem fazer.

Penso que será absolutamente necessário, no entanto, editá-las integralmente a fim de se conhecer o verdadeiro texto, sem qualquer omissão. E importa lê-las e entendê-las no seu contexto humano e social. 
Revista de História das Ideias

\title{
I
}

\section{JOSEPHUS II CARDINALIS PARTIARCHA LISBONENSIS}

\author{
A todas as Pessoas Ecclesiasticas, e \\ Seculares deste Nosso Patriarcado, \\ Saude, e Benção.
}

Não havendo cessado o PRINCIPE REGENTE, Meu Senhor, desde o principio do seu feliz Governo, de procurar affastar destes Reinos, e Dominios o flagello da Guerra, que há tanto tempo assolla a toda a Europa, sem se poupar, para esse effeito, aos sacrificos ma1s onerosos, pelo bem dos seus fiéis Vassalos: vê frustradas todas as suas diligencias pela injusta aggressão, com que a Espanha, e França querem invadir este Estado; com o unico motivo de se não haver sujeitado SUA ALTEZA REAL às iniquas condições, que ultimamente exigírão; condições que, se se acceitassem, mancharião o glorioso Governo do mesmo SENHOR com a mais execravel infamia, e opprobrio; faltando à fé dos Tratados mais solemnes, que tem com os seus Alliados; e excitando, na justa vingança destes, as hostilidades, que se devião recear de huma poderosa Potencia Maritima irritada; e as incalculaveis calamidades, que resultarião aos seus Póvos. Taes são as condições, que a Espanha requereo bem differentes das que se devião esperar do titulo de Medianeira, que aquella Corte acceitou, e bem contrarias àquellas, que, com este mesmo titulo, tinha proposto, com muita instancia, a SUA ALTEZA REAL; sobre a fé das quaes o mesmo SENHOR acabava de Nomear, e de Enviar, com a approvação da mesma Corte, hum Ministro para ajustar as differenças, que tinha com o Governo de França. Porém, inesperadamente, com manifesto desprezo de todas as referidas circunstâncias, e dos Vinculos mais Sagrados do Sangue, e da Alliança, que unem tão estreitamente as duas Monarchias; e esquecida dos soccorros, que o PRINCIPE REGENTE Meu SENHOR, tão recentemente lhe havia mandado ao Roussillon, com dispendio do Sangue dos seus Vassallos, e de avultadas sommas do seu Real Erario; e não menos da Protecção, que havia concedido aos seus Navios, entre os quaes se contão alguns bem importantes da America; mandou propôr, como condição indispensavel, para se obter a Paz com a França, e continuar a da mesma Espanha, que se fechassem os Pórtos destes Reinos a todos os Navios Inglezes, e se abrissem para os Francezes, e Espanhoes; depois de ter expressamente declarado, que a Paz se faria sobre o Tratado de Utreche, servindo este de baze; sem que bastassem todos os meios de Conciliação, que SUA ALTEZA RFAL propoz, ainda que erão bem vantajosos para as duas Nações referidas; fazendo logo, contra todos os Direitos, Divino, Natural, e das Gentes, publicar a Guerra contra estes Reinos; Guerra, para ane certamente não houve a menor provocacão da parte-do PRINCIPE REGENTE Meu SENHOR; antes exhaurido todos os meios de a evitar, para pounar o Sangue dos seus Vassallos, que lhe hé mui precioso: porém com a mesma constancia procurará repellir a forca com a força, nara resistir a huma Guerra a mais injusta, que se tem visto entre as Nações civilizadas; pondo toda a sua confiança no Deos dos Exercitos, Vingador das inivsticas $E$ nosto que confiados Nós em aue os Nossos amadns Subditos, animados dos mesmos motivos, e lembrados de aue são Portuguezes, e successores daquelles, que tantas vezes triunfárão dos mesmos inimigos; e que, apezar do seu excessivo poder, tão gloriosamente restituírão a Coroa de Portugal à Augusta Casa, que, por feli- 
cidade nossa, tão legitimamente a occupa, darão agora na defensa desta, e do Estado, os mesmos testemunhos, que sempre derão do seu Valor, Zelo, e Fidelidade; e principalmente a hum PRINCIPE, que pela Sua Bondade, Justiça, e Religião merece os maiores; como todo o bem só se deve esperar de Deos, devemos dirigir a este SENHOR as mais fervorosas súpplicas pelas mãos, e Intercessão da nossa Santissima Padroeira, e Protectora a VIRGEM SANTISSIMA, para que se digne de Abençoar huma defensa tão justa. E para que sejão mais agradaveis à Divina Magestade, e mais efficazes os nossos rogos, Mandamos a todos os Ecclesiaticos, Seculares, e Regulares deste Patriarcado, que em todas as suas Igrejas fação Preces publicas, por tres dias successivos, com o Santissimo Sacramento exposto à porta do Sacrario, pelo feliz successo das Armas Portuguezas; e que em quanto não cessar a referida causa, se fique continuando em todas as Missas a Collecta Pro tempore belli.

Exhortamos finalmente a todos, e cada hum dos Nossos Subditos, que não cessem de rogar a Deos com tão justo motivo, apartando-se de tudo, o que possa fazer menos acceitas as nossas Oracões. E para que chegue à noticia de todos, Mandámos passar a presente, que será publicada à Estação da Missa Conventual, e affixada nas Portas das Igreias, e lugares publicos na forma do costume.

Dada na Junqueira sob Nosso Signal e Sello das Nossas Armas, aos quatorze de Março de mil e oitocentos e hum.

\title{
J. CARDEAL PATRIARCA
}

\section{Tomaz Antonio Carneiro}

(O exemplar que possui o Arquivo da Cúria Patriarcal de Lisboa foi impresso na oficina de António Rodrigues Galhardo, mas é autêntico pois tem o selo de chapa usado na Câmara Patriarcal).

\section{II}

\section{JOSEPHUS II CARDINALIS PATRIARCHA LISBONENSIS}

\author{
A todas as Pessoas Ecclesiasticas, e \\ Seculares deste Nosso Patriarcado, \\ Saude, e Benção.
}

Havendo Sua Magestade Catholica, pelo Manifesto publicado em Madrid aos vinte e sete de Fevereiro proxime passado, declarado a Guerra a esta Coroa, mostrando pelas fantasticas, e suppostas razões do mesmo Manifesto a injustiça deste procedimento; e tendo as Tropas Hespanholas entrado iá nas Fronteiras deste Reino, fazendo nelle huma Guerra Offensiva; Guerra para que não houve a menor provocação da parte do PRINCIPE REGENTE, Meu SENHOR, antes pelo contrário SUA ALTEZA REAL tem procurado, por todos os modos, affastar destes Reinos esse flagello, até sujeitando-se a Sacrificios onerosos, para poupar o sangue de seus Fieis Vassallos, que ama como a Filhos; e Guerra tão contraria aos Vinculos do Sangue, e dos Tratados, que unem estreitamente as duas Monarchias; e não menos opposta à boa fé, e promessas de Sua Magestade Catholica; e Guerra. em fim, nor todos os titulos, a mais injusta; se vê precisado o PRINCIPF, REGENTE, Meu SENHOR, a repellir a força com a força, e a resistir a 


\title{
Revista de História das Ideias
}

huma tão injusta aggressão, usando dos meios, que a Divina Providencia poz nas suas Mãos, para a justa, e necessaria defensa dos seus Reinos, e Vassallos. E posto que, confiados Nós em que os Nossos amados Subditos, lembrados de que são Portuguezes, e Successores daquelles, que, tantas vezes, triunfárão dos mesmos inimigos; e que, a pezar do seu excessivo poder, tão gloriosamente, restituírão a Coroa de Portugal à Augusta Casa, que, por felicidade nossa, tão legitimamente a occupa, darão agora, na defensa desta, e do Estado, os mesmos testemunhos, que sempre derão do seu valor, zelo, e fidelidade; e principalmente a hum PRINCIPE, que, pela sua Bondade, Justiça, e Religião, merece os maiores. Como porém todo o bem só se deve esperar de DEOS, rectissimo Vingador das injustiças; devemos dirigir a este SENHOR as mais fervorosas supplicas, pelas Mãos, e Intercessão da Nossa Santissima Padroeira, e Protectora, a VIRGEM SANTISSIMA, para que se digne de Abençoar huma causa tão justa: E para que sejão mais agradaveis à DIVINA MAGESTADE, e mais efficazes os nossos rogos, Exhortamos a todos os Ecclesiasticos Seculares, e Regulares destes Patriarcado, que além das Preces publicas, que já Mandámos fazer. e da Collecta Pro tempore belli, que se deve continuar, em quanto não Mandarmos o contrario; não cessem de rogar a DEOS com tão justo motivo, apartando-se de tudo o que possa fazer menos acceitas as nossas Orações.

E para que chegue à noticia de todos, Mandámos passar a presєnte, que será publicada à Estação da Missa Conventual, e affixada nos Lugares do costume.

Dada na Junqueira, sob Nosso Signal, e Sello das Nossas Armas, aos trinta de Maio de mil oitocentos e hum.

\section{J. CARDEAL PATRIARCA}

\section{Thomaz Antonio Carneiro}

(Exemplar impresso na oficina de Antonio Rodrigues Galhardo. Embora não se veja o selo de chapa, o documento é autêntico).

\section{III}

\section{JOSEPHUS II CARDINALIS PATRIARCHA LISBONENSIS}

\author{
A todas as Pessoas Ecclesiasticas, e \\ Seculares deste Nosso Patriarcado, \\ Saude, e Benção.
}

Já que, amados Filhos, a Nossa cançada idade, e o pezo das muitas molestias, com que a Divina Misericordia nos tem favorecido, nos não podem permitir o fallar-vos de viva voz, na presente occasião; podemos com tudo dirigir-vos, como Vosso Pai, e Pastor, por este modo, como iá o fizemos pelos Nossos Parochos, e Prégadores, os Nossos Sentimentos. e Exhortações, para que o SENHOR, no fatal dia, nos nao argua de omissos neste essencial, e importante dever do Nosso Sagrado Ministerio; que todo se dirige a unir-vos em Caridade Christã; para conseguireis o Socego, e a Paz, de que todos necessitamos, nas presentes circumstancias.

Sim, amados Filhos, Vós bem sabeis, pela propria experiencia, a situação, em que nos achamos; mas tambem não ignorais o quanto 
a Divina Clemencia, no meio mesmo de tantas tribulações, nos favorece: Bemditos sejao sempre os Seus Altissimos Juizos! He pois muito necessario, amados Filhos, ser fiel aos immutaveis Decretos da sua Divina Providencia; e para o ser, devemos, primeiro que tudo, coin Coração contricto, e humılhado, agradecer-lhe tantos, e tão contınuos beneticios, que da sua liberal Mão temos recebido; sendo hum delles, a boa Ordem, e quietação, com que neste Reino tem sido recebido hum grande Exercito, o qual, vindo em nosso soccorro, nos dá bem fundadas esperanças de felicıdade; beneficio, que igualmente devemos à actividade, e boa direcção do General em Chefe, que o commanda, cujas Virtudes são por Nós, há muito tempo, conhecidas.

Não temaes, amados Filhos, vivei seguros em vossas casas, e fora dellas; lembrai-vos que este Exercito hé de Sua Magestade o Imperador dos Francezes e Rei de Italia, NAPOLEÃO o Grande, que Deos tem destinado para amparar, e proteger a Religião, e fazer a felicidade dos Póvos; Vós o sabeis, o Mundo todo o sabe: Confiai com segurança inalteravel neste Homem prodigioso, desconhecido de todos os Seculos: Elle derramará sobre nós as felicidades da Paz, se Vós respeitareis as suas Determinações; se vos amareis todos mutuamente, Nacionaes, e Estrangeiros com fraterna Caridade: Deste modo a Religião, e os seus Ministros, serão sempre respeitados; não serão violadas as Clausuras das Esposas do SENHOR; o Povo todo será feliz, merecendo tão Alta Protecção: Meus Filhos, fazei-o assim, para cumprireis fielmente com o que Nosso Salavdor JESUS CHRISTO tanto nos recommenda: Vivei sujeitos aos que vos governão, não só pelo respeito, que se lhes deve; mas porque a propria Consciencia vos obriga.

Tornamos finalmente a recommendar muito a todos os Parochos, Nossos Coadjutores, e mais Clero deste Patriarcado, e até lho pedimos pelas Entranhas de JESUS CHRISTO, que concorrão, quanto lhes for possivel, para esta união, em todas as occasiões, e Lugares; instruindo os Póvos de tal sorte, que elles possão bem conhecer as vantagens, que, em o assim praticarem, devem conseguir.

$\mathrm{E}$ para que chegue à noticia de todos, Mandámos passar a presente, que será publicada à Estação das Missas Conventuaes, e affixada nos Lugares do costume.

Dada na Junqueira, no Palacio de Nossa Residencia, sob Nosso Signal, e Sello das Nossas Armas, aos oito de Dezembro de mil oitocentos e sete.

\section{J. CARDEAL PATRIARCA}

Thomás Antonio Carneiro

(Exemplar impresso na oficina de António Rodrigues Galhardo, mas autêntico pois tem o selo de chapa da Câmara Patriarcal).

\section{IV}

DOM JOSE MARIA DE MELLO, BISPO TITULAR DO ALGARVE, INQUISIDOR GERAL NESTES REINOS, E SEUS DOMINIOS, DO CONSELHO DE SUA MAGESTADE, E SEU CONFESSOR, ETC.

A todos os Fiéis da Santa Igreja Lusitana, a cuja noticia vier esta Nossa Carta, saude,

e a Paz, e a Graça de Nosso Senhor JESU CHRISTO, Nosso Salvador, e Nosso Deos. 
O Lugar de Inquisidor Geral nestes Reinos, que sem méritos Occupamos: O Caracter, e Ordem Episcopal, de que Nos achamos revestidos: O Zelo exemplar com que o Eminentissimo, e por tantos titulos mui Veneravel Cardeal Patriarca acaba de promover tão efficazmente com a sua moderna Carta Pastoral o socego, a paz, a união christã particular, e pública; sempre necessaria, e muito mais nas circunstancias presentes: Tudo isto Nos faz lembrar que também da Nossa parte Deviamos concorrer para hum fim tão importante, e tão indispensavelmente necessario não só para o bem, e felicidade temporal, mas tambem para a eterna, que hé o que mais importa, Dirigindo-Nos aos Fiéis todos da Santa Igreja Lusitana, e exhortando-os tambem Nós.

Aos desta Cidade, e Patriarcado nada Temos que dizer, senão só rogar-lhes muito que attendão as zelosas vozes do seu tão Veneravel Pai, e Pastor, como devem sempre, e em tudo, porém muito mais em materia tão importante para o bem de todos, para o bem de cada hum, para a felicidade temporal, para a felicidade eterna.

Ao resto dos Fiéis desta Lusitana Igreja que outra cousa tambem lhes Podemos lembrar mais propria, do que o que às suas Ovelhas ensina, e encommenda aquelle tão Insigne Pastor? Que bem sabem pela propria experiencia a situação em que nos achamos, mas tambem que não ignorão o quanto a Divina Clemencia no meio mesmo de tantas tribulações nos favorece; bemditos sejão sempre os seus Altissimos Juizos! Que hé muito necessario ser fiel aos Immutaveis Decretos da sua Divina Providencia, e que para o ser devemos primeiro quc tudo com coração contricto, e humilhado agradecer-lhe tantos, e tão contínuos beneficios, que da sua liberal Mã̃o temos recebido; sendo hum delles a boa Ordem, e quietação com que neste Reino tem sido recebido hum grande Exercito, o qual vindo em nosso socorro, nos dá bem fundadas esperanças de felicidade: Que beneficio igualmente o devemos à actividade, e boa direcção do General em Chéfe, que a Commanda, cujas Virtudes são por Elle há muito tempo conhe. cidas: Que não temão: Que vivão seguros em suas casas, e fora dellas: Que se lembrem que este Exercito hé de Sua Magestade o Imperador dos Francezes e Rei de Italia, NAPOLEAO o Grande, que Deos tem destinado para amparar, e proteger a Religião, e fazer a felicidade dos Póvos: Que o sabem: Que o Mundo todo o sabe: Que confiem com seguranca inalteravel neste Homem prodigioso, desconhecido de todos os Seculos: Qve Elle derramará sobre nós a felicidade da Paz, se respeitarem as Suas Determinações; se se amarem todos mutuamente Nacionaes e Estrangeiros com fraterna Caridade; Oue deste modo a Religião, e os seus Ministros serão sempre respeitados; não serão violadas as Clausuras das Esposas do SENHOR; o Povo todo será feliz, merecendo tão Alta Protecção: Que o facam assim nara cumprirem fielmente com o que Nosso Salvador JESU CHRISTO tanto nos recommenda: Que vivão sujeitos aos que os governão, não só pelo respeito, que se lhes deve, mas porque a propria consciencia os obriga.

Eis-aqui o que o tantas vezes Respeitavel Pastor desta Cidade e Diocese ensina, e encommenda às suas Ovelhas para as unir em Caridade Christã, para conseguirem o socego e a paz, que todos necessitamos nas presentes circunstancias: Eis-aqui o que Nós querendo concorrer, como tanto Devemos, para os mesmos fins, Lembramos ao resto dos Fiéis desta Igreja Lusitana.

E por quanto esta materia hé huma das da maior importancia, mesmo para a conservação da pureza da Nossa Santa Fé e Santa Religião; pois tanto concorrerá sempre para ella o socego, a paz, a 
união particular, e pública: Não Contentes Nós com esta diligencia, que por Nós mesmo Fazemos nesta Nossa Carta: Encarregamos mui encarecidamente aos Deputados do Conselho Geral, aos Inquisidores, e mais Ministros do Santo Officio, que com todo o desvélo, applicação, e efficacia concorrão com a admoestação, com a exhortação, com a persuasão, assim como concorrem sem dúvida, e hão de concorrer sempre com o exemplo, para que o mesmo socego, paz, e união não tenhão quebra ou mingua alguma, mas antes augmento sólido e constante.

Encommendamos tambem, e mui especialmente, a todos os Regulares deste Reino em geral, e a cada hum delles em particular, que além do exemplo, que sem dúvida hão de dar, como aquelles que são, não só Ministros de hum Deos de Paz, e lhe offerecem quotidianamente o Sacrificio de Propiciação, e Pacificação, mas seguidores por Instituto, e Profissão da Perfeição Evangelica, se empenhem em não perder ocasião de lembrar aos Fiéis o quanto hé da s'a obrigacão como taes, o quanto lhes hé proveitoso, o quanto lhes hé necessario esse socego, essa paz, essa união, em recommendar a qual não poderá haver nunca demazia.

Da Misericordia Infinita do Nosso Bom Deos, Esperamos que se digne de abençoar todas estas diligencias, e então sem dúvida hão de produzir o bem effeito a que se encaminhão.

E para que esta Nossa Carta chegue à noticia de todos, as Mezas das Inquisições deste Reino a fação publicar, e affixar nas Igrejas dos seus Districtos, na fórma do costume.

Dada em Lisboa sob Nosso Signal, e Sello do Conselho Geral do Santo Officio aos vinte e dois dias do mez de Dezembro de mil oitocentos e sete annos.

Manoel Correa da Fonceca, Secretario do mesmo Conselho Geral, a fiz escrever, e sobscrevi.

\section{JOSE BISPO INQUISIDOR GERAL}

Lugar + do Sello

$\mathrm{Na}$ Officina de Joaquim Thomás de Aquino Bulhões

(Exemplar impresso pertencente a uma coleç̧ão particular)

\section{CARTA DO CABIDO DE LÏSBOA, SEDE VACANTE, PARA O PRINCIPE REGENTE}

Senhor

O mês de Fevereiro do corrente anno hé sem duvida a mais funesta Época de Portugal pelos infelizes acontecimentos que nelle ocorrerão que singularmente farão sensiveis à Santa Igreja de Lisboa, e que vierão com muita particularidade preparar e occazionar as maiores violencias ao Collegio dos Principaes.

O dia primeiro do dito Mez foi o assignalado pelo inimigo de Deos, e dos homens, para decretar se a Ruina de Portugal, impondo-se-lhe huma Contribuição, que excedia as suas possibilidades e sobre tudo annunciando-se que este Reino perderia a grande ventura de 
continuar Vossa Alteza Real a ser o nosso Augusto Soberano, Senhor e Pay.

O dia treze do mesmo Mêz hé aquelle em que o nosso Santo Pastor [o Cardeal Mendonça] não podendo sobreviver aos dezastrozos successos que cada dia se estavão observando, passou a melhor vida e nos deixuu a maior, e mais justa Saudade; Entrámos desde logo no Governo do Patriarcado, na forma de Direito; confirmámos o Vigario Geral e mais Ministros da Relação e Curia Patriarcal, bastando para a nossa confiança nelles a que tinhão merecido ao respeitavel Prelado que Deos acabára de chamar à sua Divina Prezença.

Pelo infame Decreto acima mencionado se despojou a nossa Igreja assim como as outras de toda a sua prata e Ouro, apezar de efficazes dezejos que tivemos para impedilo; isto porem não obstante sempre continuou o Culto Divino pelo mesmo modo; sempre as Festividades se tem celebrado, como d'antes, e para assim o conseguirmos recorremos imediatamente aos sobrecelentes da Igreja de Mafra; tão generozamente dotada pelo nosso Augusto Fundador e por Vossa Alteza que nenhuma falta conheceu nas Alfaias que com nosco repartio.

Era este o unico recurço que tinhamos pois que em nove Mêzes de oppressão, nenhum só real nos foi dádo para guizamentos, os quaes suprimos com o producto de alguns fructos das Lezirias que vendemos.

Succeder Senhor a hum Preládo tão digno, qual o que acabamos de perder, hé sempre tão penozo quanto são difficeis de imitar Suas heroicas virtudes, e Seu Santo Zelo nas importantes Obrigaçoens do Seu Sagrado Ministerio; entrar porem nesta Successão, quando a Impudencia e o Orgulho de hum fingido Protector, e verdadeiro inimigo, tem a uzurpada posse do Imperio Civil, hé muito particularmente penozo, violento, e dezagradavel: hé isto o que nos succedeu no desditozo t€mpo em que hum Governo intruzo nos violentava à Assignatura de Papeis que macularião a nossa honra, e gravarião a nossa Consciencia se não fosse tão constante a Deos e ao Mundo a nossa lealdade, e a oppressão em que nos achavamos constituidos, não nos sendo então possivel, nem chegar por este meio ao Throno de Vossa Alteza Real, a protestar-mos a nossa inalteravel Obediencia respeito, e fidelidade.

Mas o nosso bom Deos faz succeder a luz às trevas aos horrores de Fevereiro succedem no Norte, e Sul desde Reino as demonstraçoens de Valor e Patriotismo que no Mês de Junho começão a patentear-se, e que no dia quinze de Setembro, com o auxilio das Tropas Britanicas, e sobre tudo por effeito da Divina Providencia que vigia em nosso favor concluem a prodigiosa obra da nossa felicissima Restauração.

Já rendemos graças ao Ceo por tão incomparavel beneficio; o mesmo Ceo prezerve a Vossa Alteza e Sva Augusta e Real Familia de todo o mal, e o guarde pelos dilatados Annos que a nosso Senhor pedimos, e havemos mister.

Lisboa em Collegio Sede Vacante 28 de Outubro de 1808.

E. Principal Silva I. Principal Decano L. Principal Castro

(Copiámos estie documento do seguinte livro: Angelo Pereira, D. João VI Principe $e$ Rei-III A independencia do Brasil), Lisboa, Empresa Nacional de Publicidade, 1956, pp. 121-122). 
Pastorais de alguns Bispos Portugueses

\author{
VI \\ PASTORAIS DE D. FR. MANUEL DO CENACULO \\ VILAS BOAS, ARCEBISPO DE EVORA* \\ (Cópias da época)
}

A

Pastoral que os Generais do Exército Francês, com as armas na mão, obrigaram Sua Ex." Revma. a escrever.

Da pacem. Domine, in diebus nostris.

Dai-nos, Senhor, paz em nossos dias.

Dom Fr. Manuel do Cenáculo Vilas Boas, por mercê de Deus e da Santa Sé Apostólica, Arcebispo Metropolitano de Evora, etc. Cristo.

A todos os fieis desta nossa Diocese, saude e benção em Jesus

Acudir às urgências do Povo com as instrucões necessárias e avisos oportunos é da nossa obrigação pastoral. Nesta inquietacão conseguinte é necessário fazer ver aos fieis o perigo de um arbítrio que nem sempre saudável nem útil. Quis a Providência Divina que a nossa obediência e sujeição fosse dirigida e determinada pelo Governo do Invencivel Napoleão. E necessário assentar em base firme para a segurança dos nossos passos. A instrução apostólica não se ocupa com questões, o que de direito se nos apresenta é o que temos nas Sagradas Escrituras: obedecer a quem nos preside. Isto assim observado vem a tranquilidade com todos os seus bens consecutivos. A este desemnenho vos exorto e aconselho, certos em que esta obediência e accão cristã não há lugar de questões. Sempre delas se tira moléstia e desassossego, por outra parte sobre os bens negativos o bom cristão deve obrar com virtudes positivas; acreditar o melhor e obrar com aprovação meritória e decisiva. Isto assim bem entendido e tomado em justa resolução cumpramos obedecendo aos Superiores da actual situação e do Império do Invencivel Imperador e Rei Napoleão, e entremos em sossego no governo das nossas vidas, cada $\mathrm{um}$ na sorte que Deus nos dispensou, viveremos contentes e em tranquilidade.

Dada em Evora aos 30 de Julho de 1808.

Fr. Manuel, Arcebispo de Évora

\title{
B
}

Pastoral que o Exmo. e Rvmo. Senhor Arcebispo de Évora, obrigado pelos Generais do Exército Francês, escreveu à sua vista, proibindo ao Clero o uso de armas

Enquanto o meu género de vida me não facilita para um longo discurso sobre a matéria que devo tratar, contudo sua qualidade importante $e$ os seus abusos, que se devem evitar, penhoram-me para enunciar do modo possivel até que melhora dos dias dêem ócio e frase. O objecto não é menos que a reprovação de um abuso pernicioso ao Estado Moral e Eclesiástico. E a reprovação, digo, de se armarem os Eclesiásticos militarmente, segundo lhes inspira a sua imaginação

* Actualizámos a ortografia visto tratar-se de simples cópia. 
indisciplinada e extravagante. Sistema é este oposto ao Evangelho que professamos. Este manda ser o Eclesiástico manso e humilde, ele veda o fogo e ferro manejado pelo Eclesiástico, ele nos proíbe ser guerreiros e gente armada. Nossa Milícia é para contender com os vícios e propagar a virtude. Quanto é dissonante destes exercícios uma vida guerreira mal animada e mal comportada. $O$ braço que sustenta a Arca do Testamento seria torpemente distraído para empunhar o ferro e o aço. Seria introduzir no Santuário o abuso e o vício. Não há engenho, nem arte, que façam concordar a doçura Evangélica e o estrondo das armas. Aquela é a nossa vocação legítima. O contrário seria viver exposto à sanha militar para descrédito e demonstrações tristes. Por estas ideias deve o Eclesiástico regular sua vida para nem desagradar à Divindade que o quer humilde, nem às Potências Temporais, que tiram o escândalo de semelhante abuso. $\mathbf{O}$ alvoroço militar que lhe recomendamos é a pronta obediência às vozes da Sabedoria quando chama para a sua Fortaleza e para guarnecer as muralhas da cidade com a valentia da Doutrina e Virtude, quando os interessa na vigia contra os assaltos dos inimigos da alma e põe em alerta para preservar dos insultos. Ocupados os Eclesiásticos destas obrigações jamais se deixarão enganar pelo atractivo da armadura que lhes é incompetente. A Armadura Doutrinal para que a Sabedoria nos convida é a que a mesma Sabedoria Encarnada ostentou entre os homens, e dela deu mostras no Tabor onde ensinou a Ocupação Sacerdotal Servindo aos Mistérios e Sacramentos da Lei, dos Profetas e do Evangelho. Confiamos que pelo arbítrio de inspirar aos Professores do Nosso Estado os argumentos por que se devam dirigir nos actos da sua vida haverão de conformar-se todos ao Clero escolhido e modesto e ao Espírito das Santas Escrituras. Contudo para o fazerem meritoriamente, mandamos ao clero de um e outro Estado, Secular e Regular, não tenham em seu poder, nem usem de armas, que lhes são defesas, e as deponham no Depósito Público, aonde o Governo desta Cidade as tem mandado fechar.

Este nosso Edital será lido nas Igrejas desta Cidade.

Dado em Evora sob nosso sinal e selo aos 6 de Agosto de 1808. Fr. Manuel, Arcebispo de Évora.

\section{C}

Pastoral que Sua Ex." Revma, sendo para isso intimado, escreveu e entregou, no tempo da sua prisão, aos Deputados da Junta de Beja

Salvo dos fatais destroços da Capital da minha Metrópole Évora, facilmente aproveito esta Graça para repetir as observaçōes necessárias na outra minha antiga e agora canonicamente por mim administrada Capital do Bispado de Beja. Moisés temeu os destroços dos seus irmãos no Egipto e protestou a Deus visitar e observar os que ainda viviam: Vadam et revertar ad fratres meos, ut videam si adhuc vivant. Esta imponderável Graça de achar os Bejenses sãos e salvos de tristíssima ruina comove a entranha para agradecer a Deus tão sensivel Benefício. Seus efeitos devem ser tocados em particular para animar os Povos. Ainda vivemos, Amados Bejenses, ainda vos resta o mesmo espírito de vida e de Doutria, ainda a Graça Divina nos fez superiores à turbulenta animosidade que se atreveu contra as nossas respirações e alentos. Sim, é favor extraordinário da Providência que nos vejamos e escutemos uns aos outros dizendo-nos: A força bruta dos Demónios 


\section{Pastorais de alguns Bispos Portugueses}

que tanto mal sugeriram aos homens e fizeram, mas achou de encontro a Dominação celeste para nos proteger e defender, como respeitamos no Bem-aventurado Arcanjo que neste feliz território por nós interceda, agora mais do que nunca verificou a sua Denominação: Michael quis ut Deus. Sim, a Omnipotência Divina ainda foi servida conservar nestes Lares as Demonstrações da sua virtude infinita. Ainda mostra querer a continuação dos seus auxílios para connosco. Ainda faz internecer vosso Pastor à vista da vossa Religiosa Piedade, à vista da vossa Resignação para com as Permissões da sua Justiça. A vista, digo, de vossas carinhosas e constantes afeições para a nossa antiga devoção ao Senhor Sacramentado. Não é possivel que vos desprendam desta filial afeição quaisquer outros cuidados temporais, nem o necessário emprego para as coisas da milícia, nem os cuidados económicos e domésticos, nem o Estudo, nem as Letras tenho conhecido serem capazes de vos desviar e separar do Sacramento, que em boa hora penetrou vossos corações na Adoração da Santíssima Eucaristia. A este Maior dos Mistérios atribuo a preservação de maiores males, a conservação da vida nas instantes angústias, sabendo entreter-se judiciosamente com as temporalidades indispensáveis nos ofícios da vida, nos empregos honrados, que a distinguem, no amor da Pátria que a coonesta. Alegre com a invenção deste Tesouro, com a animacão dos vossos espíritos e constância de vossos propósitos pela Religião, pela Justiça e Lei, vendo vos inferessados pelo Amado Príncipe e pela Pátria, enquanto me não repito a vós e a vossos festivos clamores de alegria, volto a outros indispensáveis ofícios, tendo presentes a Minha Palavra e a Vossa Fé. Dada em Beja sob nosso sinal e selo de nossas armas, aos 8 de Setembro de 1808.

Fr. Manuel, Arcebispo de Évora

\section{D}

\section{Dom Fr. Manuel do Cenáculo Vilas Boas, por mercê de Deus e da Santa Sé Apostólica, Arcebispo Metropolitano de Évora, etc.}

No exame dos tempos e de suas inconstâncias, cuidadosos Clero, se estabelece a concórdia dos Direitos. A todos eles vivem os homens sujeitos e o cumprimento das obrigações de ciência dos objectos e da natureza dos ofícios. E necessário saber o que se manda, quando, por quem, e para quais fins. Havemos já proposto à vossa atenção e observância a índole pacífica do nosso Estado e que a profissão das virtudes cristãs são na frase de $\mathrm{S}$. Paulo as nossas armas justas e competentes para todos os casos da vida (Cor. 2.", cap. 6.'). Assim o dissemos em uma das nossas pastorais do ano passado publicámos por consciência e por atenção a nossos desempenhos Eclesiásticos cuja índole nos deve ser patente e a devíamos explicar, mas também porque a tanto nos obrigou a instância de um Exército irritado, de cujo Conde General e seus Ajudantes dentro mesmo dos nossos lares ouvimos o preceito de que por força de uma Proclamação proibíssemos o nosso Clero o uso das armas, o qual já então seria inutil e perdido. Quando porem outros tempos pedem outros costumes, quando a Religião e a Pátria com seus interesses, afecto (?) e comodidade perigam, quando as vidas, ainda pessoais do clero se acham ameaçados de ferocíssima e incontinente invasão, para este caso é que se reservam as excepções do Direito Comum, salva muito bem esta contradição no que se manda, e determinadamente sobre as acções de peleja, a res- 
peitável autoridade de Santo Atanásio, o qual escrevendo ao grande amigo de Deus o Santo Monge Amune desenganadamente resolve que nas coisas do costume da vida humana em algumas ocorrem variedades às quais se há de prover com distinção, como é proibir a peleja, mas promovendo a morte dos nossos violentos inimigos. Assim pois fora de risco prejudicial e nocivo cada um se contenta nos termos de seu instituto e vocação. 0 soldado instrua-se no ócio para o combate, o eclesiástico exercite-se nas coisas da Religião para merecer de Deus as graças, e quando ao Senhor dos Exércitos não desagradar que ele resista a seus inimigos para a conservacão da vida pessoal e dos Mistérios, confirme-se nestas intenções e disponha-se para as servir, pois que nos combates receberá da mão do Senhor Reino de honra e coroa de formosura porque com sua dextra a cobrirá e com o seu Santo Braço o defenderá.

A Divina Sabedoria por seu zelo tomará suas armas e armará as criaturas para a vingança dos inimigos, vestir-se-á de Justiça por arnês saia de malha e peitoril e por elmo tomará o juizo certo, e inexpugnavel em auxílio do que peleja, e acode por sua causa. Aguçará sua inexorável ira e pelejará com o Justo Senhor todo o universo contra os insensatos. Tanto é o que se promete ao eclesiástico necessitado para combater e apurado e disposto com suas rectas intenções na Divina Justiça a qual serve. As medidas para este santo zelo direi tomar-se e praticar-se com a discrição que pede o zelo e com a economia das acções. Fique empregado no Culto e nas Santidades da vida e narte do clero que para tanto sirva, outra parte do mesmo ore, flage[le]-se com penitência e macerações, entrelace com vigílias e penitências os suspiros as preces e as lágrimas, e dando ao céu este prazer pelas nossas humilhações, darme-nos (?) por castigados, porque ainda o céu em demonstração de pena permite que sejamos punidos com esta distração de nossos Ofícios Eclesiásticos. mas satisfazendo-lhes auanto é possível. a porção robusta do Sacerdócio passe ao emprego bélico para o aue é rogado e mandado, defenda-se a si. evite os prejuizos da Pátria, salve-a de tiranias inimigas e seus tristes efeitos conseguintes. Conservando no Santuário o Divino Culto, dando-se à Divindade a glória competente. o resto vingador e apto para este desempenho, tome a armadura aue lhe nermite a estacão e o zelo e atreva-se que como a .Justica Divina lhe consente para defender a inocência e dar impunidade à virtude acometida.

Nestas disposicões poderá o Clero (como temos visto a respeito dos Seculares inexpertos) tomar as instruções secretas de armamento, peleja e manobra oportuna.

$\mathrm{E}$ para que cheque à notícia de todos mandámos que esta seja lida repetidas vezes à Missa Conventual.

Fevereiro, 2 de 1809.

(Biblioteca Pública e Arquivo Distrital de Evvora - Manisola $\left.-30-11, n .^{\circ} 1,2,3\right)$. 